
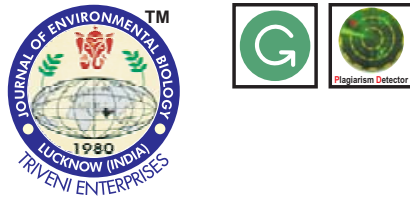

\title{
Performance evaluation of a landfill leachate recirculation treatment system using quadric model
}

\section{Authors Info}

\section{R. K. Lohchab* and U. Singh}

Department of Environmental Science and Engineering, Guru Jambheshwar University of Science and Technology, Hisar-125 001, India

${ }^{*}$ Corresponding Author Email : rajeshlohchab@gmail.com

Key words

Quadric model

Anaerobic treatment

Bioreactor

Leachate

Municipal solid waste

Publication Info

Paper received : 31.05 .2016

Revised received : 12.10.2016

Re-revised received : 01.02.2017

Accepted : 23.03.2017

\begin{abstract}
Aim : The present research was carried out to study the effects of recirculation of leachate in cylindrical shaped anaerobic bioreactor on treatment of leachate as well as stabilization of municipal solid waste. Quadric and regression model were used to study the behavior of operating parameters over time scale and on COD, respectively.
\end{abstract}

Methodology : $19 \mathrm{~kg}$ of solid waste was filled and compacted and in reactor and water was added to it till 20 liters of leachate prepared. The whole unit was sealed air tight and leachate was recirculated @ 28m//min for 12 hours daily. Physico-chemical characterization of leachate and and solid waste was done by using standards methods of analysis.

Results : Results shows that the parameters like pH (6.69 to 7.74$)$, alkalinity (7100 to $1600 \mathrm{mg} \mathrm{l}^{-1}$ ), VFA alkalinity ratio (1.44 to 0.33$)$ etc. were within the optimum range of anaerobic degradation. COD is an indicator of organic contamination and a reduction in 96\% COD was observed at the end of 29 weeks of leachate recirculation. The quadric model also confirms that the most of organic and inorganic contaminants of leachate were decreased and alkalinity was increased with time. In addition to leachate treatment, a reduction of $26.3 \%$ volume of MSW was observed after completion of study.

Interpretation : The performance of Leachate Recirculation Bioreactor was excellent as most of organic and inorganic contaminants were decreased and $\mathrm{pH}$ and alkalinity were increased with time. Thus, this technology can be a good solution of MSW problems of countries like India which demands urgent attention in this direction as it treats the leachate as well as stabilize the solid waste.

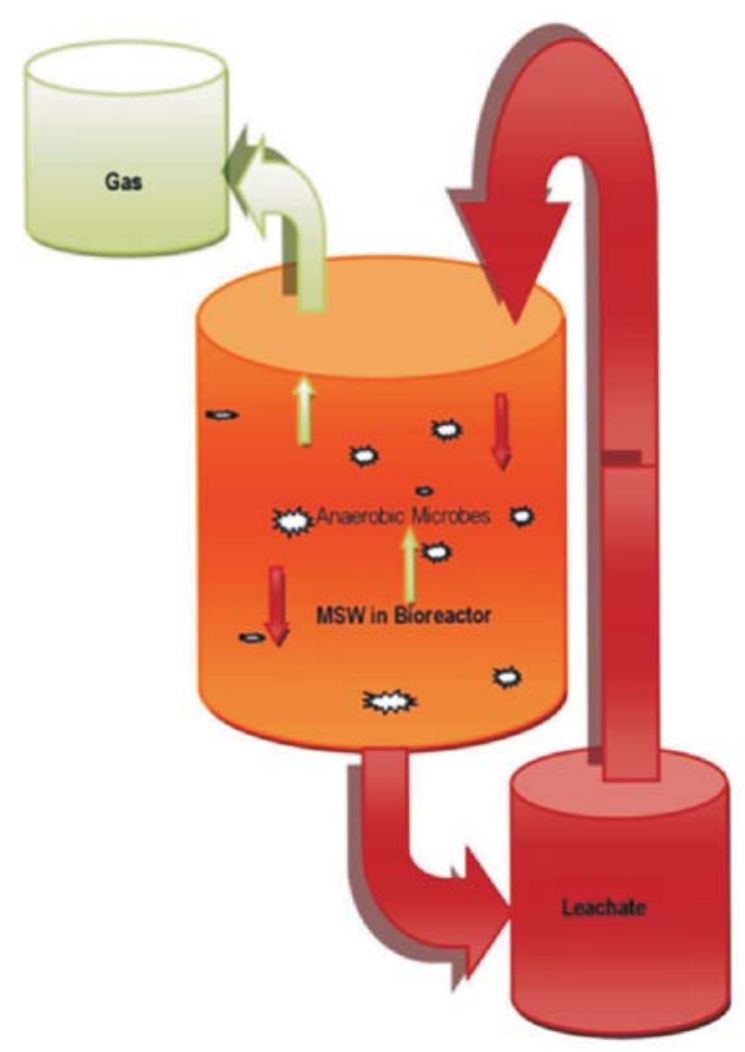




\section{Introduction}

Solid waste generation has increased and its composition has also changed with increase in population, urbanization, modern life style and food habits. Municipal solid waste generation has shown a positive correlation with economic development on a global level. Strategic review and planning can play a significant role in reducing the direct and indirect impact of waste on the environment. No single technology is adequate for complete management of waste and hence, city-specific combination of technologies should be adopted for sustainable waste management (Mor et.al., 2016).

Solid waste disposal is a difficult task as more land is required for ultimate disposal. The conventional and principal method of MSW disposal in developing countries is open dumping and landfilling (Ponmani et.al., 2014). The disposal of solid waste unscientifically leads to uncontrolled dispersion of leachate.

Leachate is a liquid formed when waste breaks down in the landfill and water filters through that waste. This liquid is highly toxic and can pollute land, ground water and water ways (Kirmizakis et al., 2014). Leachate in a landfill may have high concentration of organic matter, inorganic constituents like nutrients and heavy metals and microbes including disease causing agents. The leachate requires treatment to minimize the pollutants to an acceptable level prior to discharge into water course (Aziz et al., 2010). Because of its complex composition, it is difficult to treat in order to meet the effluent standards (Chen et.al., 2014).

Landfill leachate treatment has been given significant attention in past (Bohdziewicz et al., 2001; Ahn et al., 2002). Due to high concentration of high organic matter and other pollutants, treatment of leachate is a challenging task. The biological reactions played a dominant role in the removal of pollutants ( Han et al., 2013). Pohland (1975) conducted one of the first experiments on leachate recirculation. Leachate recirculation is a relatively inexpensive option of treatment and disposal of leachate. The beneficial effects of leachate recirculation are degradation of waste, biogas production, organic load reduction in leachate and settlements of MSW (Reinhart and AL-Yousfi, 1996). It is also effective in waste volume reduction rate of landfill sites (Chan et al., 2002). Leachate recirculation increases the moisture content in a bioreactor and provides distribution of nutrients between methanogens and solids wastes/liquids. Thus, it treats the leachate at faster pace in comparison to conventional landfill at onsite without transferring them off-site for treatment or disposal. Due to heterogeneous nature solid wastes in bioreactor, the leachate may find discrete channels to travel through. It is difficult to insure that the leachate is reacting with all the waste and is thoroughly being treated. In addition to this, other operational and design problems are at risk of environmental exposure if leachate is applied to the surface and requirement of liner, leachate and gas collection and management facilities. Leachate Recirculation Bioreactor is a good technique, if applied skillfully (Bhambulkar, 2011).

The present research aimed to observe the effect of leachate recirculation on stabilization of municipal solid waste in cylindrical shaped anaerobic bioreactor. Quadric and regression model were used to study the behavior of operating parameters over time scale and on COD, respectively.

\section{Materials and Methods}

Five random samples consisting $7.5 \mathrm{~kg}$ of municipal waste each were collected from dumping site at Dhandhoor on $\mathrm{NH}-10$, Hisar. A part of properly mixed freshly collected MSW after determining moisture content was sun dried and milled and sieved through sieve size of $<2 \mathrm{~mm}$ for estimation of physicochemical properties, following the methods of Ryan et al. (2001).

The Leachate Recirculation Bioreactor setup and dimensions are given in Fig. 1. Nineteen kilograms of properly mixed MSW having $0.057 \mathrm{~m}^{3}$ volume was added by compaction to Leachate Recirculation Bioreactor. The water was added in the bioreactor to prepare $20 \mathrm{I}$ leachate. The bioreactor and leachate collection container were sealed air tight. Leachate recirculation was done @ $28 \mathrm{ml} \mathrm{min}{ }^{-1}$ for 12 hrs daily. A $10 \mathrm{ml}$ and $50 \mathrm{ml}$ leachate samples were collected on daily basis for analysis of temperature, $\mathrm{pH}$, electric conductivity, alkalinity and chemical oxygen demand and on weekly bases for analysis of total dissolve solids, total suspended solids, volatile suspended solids, sodium, potassium, total hardness, calcium, magnesium, chloride, sulphate, phosphate, total Kjeldahl nitrogen and volatile fatty acids, respectively and analyzed for various physico-chemical parameters following the standard methods of APHA (2012). The leachate volume was made up by adding distilled water equal to the volume of leachate samples collected and accordingly dilution factor was used for the calculations.

To capture the behavior of different variables related to operating parameters (physico-chemical properties of leachate) of the study in relation to time, different regression models such as linear, logarithmic and growth were employed to get the best fit of the model using SPSS 16 software. The data of above mentioned all physico-chemical properties of leachate collected on daily and weekly basis was converted to log scale and used for statistical analysis. Based on the results obtained, quadric model was found best fit to study the change in operating parameters over time scale. Thus the results of quadric model were used in the present study.

The regression model determines the relationship between dependent variable $Y$ and independent variable $X$. The effects of operating parameters on COD were studied by regression modeling. 


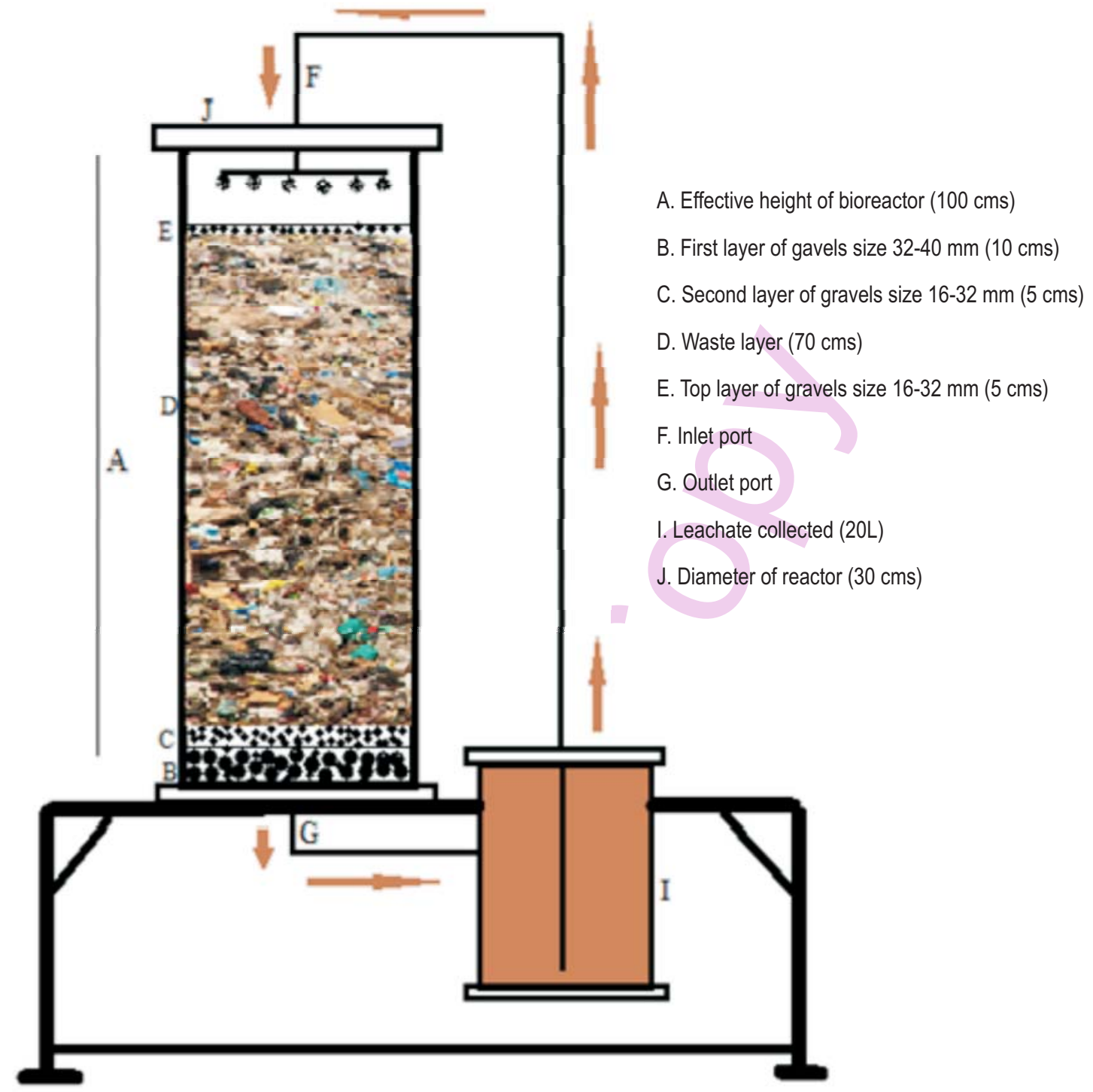

Fig. 1: Schematic diagram of leachate recirculation bioreactor

\section{Results and Discussion}

High TOC level of $48.3 \mathrm{mg} \mathrm{g}^{-1}$ of MSW indicated that biodegradable organics constituted the major composition of MSW. Mor et al., 2016 also observed highest content (52\%) of biodegradable organic fraction in MSW of Chandigarh city. After treatment, the $\mathrm{pH}, \mathrm{EC}$, total organic carbon, phosphate and TKN of MSW decreased from 7.8 to $7.3,2.8$ to $2.3 \mathrm{mS} \mathrm{cm}^{-1}, 48.3$ to 27.4 $\mathrm{mg} \mathrm{g}^{-1}, 2.3$ to $1.2 \mathrm{mg} \mathrm{g}^{-1}$, and 35 to $15 \mathrm{mg} \mathrm{g}^{-1}$, respectively (Table 1). A $43 \%$ reduction in TOC was observed after the study, whereas reduction in phosphate and TKN were $48 \%$ and $57 \%$, respectively. The initial volume of solid waste used in bioreactor for leachate preparation was $0.057 \mathrm{~m}^{3}$. However, at the end of the study it was reduced to $0.042 \mathrm{~m}^{3}$.
To carry out the leachate recirculation study, 20 I volume of leachate was prepared from MSW in bioreactor, which decreased to $18.5 \mathrm{I}$ after recirculation study due to evaporative loss. The results of change in leachate quality with time is shown in Table 2. The minimum temperature of $9.8^{\circ} \mathrm{C}$ was observed in February and maximum of $35^{\circ} \mathrm{C}$ was observed in April. The pH ranged from 6.69 to 7.74 . Initially, the $\mathrm{pH}$ of the reactor decreased from 7.10 to 6.69 in the $2^{\text {nd }}$ week of recirculation, which might be due to acidogenesis and formation of volatile fatty acids (Bohdziewicz and Kwarciak, 2008). After that an increase in pH was observed. This increase in $\mathrm{pH}$ may be due to onset of methanogenic activity which results in increase in methane gas production and decrease in hydrogen, carbon dioxide and volatile fatty acid production (Murphy et al., 1995). When methane 


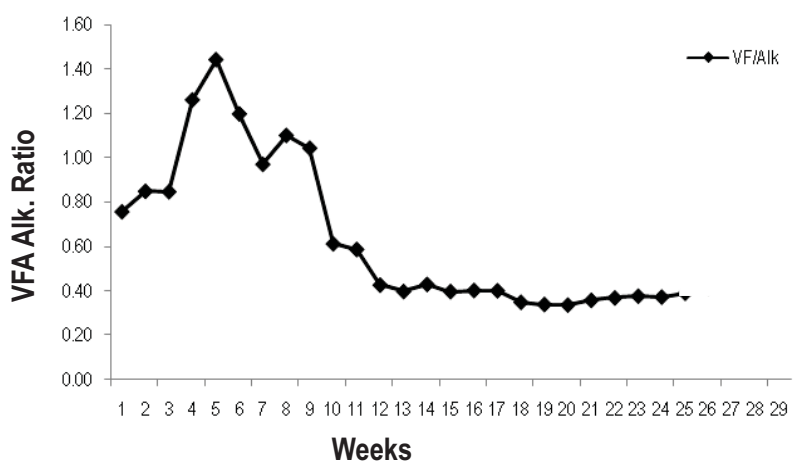

Fig. 2 : VFAAlkalinity ratio of leachate during study period

production was stabilized, the pH ranged between 6 to 8 (Ehrig, 1983). During the study period leachate conductivity increased from 9.22 to $11.45 \mathrm{mS} \mathrm{cm}^{-1}$ upto $9^{\text {th }}$ week of leachate recirculation and then it started decreasing with time. At the end of study it was $8.46 \mathrm{mS} \mathrm{cm}^{-1}$. The TDS, TSS and VSS varied from $8560 \mathrm{mg} \mathrm{l}^{-1}$ to $2780 \mathrm{mg} \mathrm{l}^{-1}, 1170 \mathrm{mg} \mathrm{l}^{-1}$ to $460 \mathrm{mg} \mathrm{l}^{-1}$ and $1050 \mathrm{mg} \mathrm{l}^{-1}$ to $180 \mathrm{mg} \mathrm{l}^{-1}$, respectively. The maximum reduction of TDS, TSS and VSS observed were $67 \%, 60 \%$ and $85 \%$, respectively. Biodegradation of organic matter over time resulted in decrease in TDS concentration. As compared to other solids, TSS removal was lower, as TSS takes longer time to decompose and disintegrate (Sartaj et al., 2010).

The results of leachate recirculation study reflect the decreasing trend of sodium and potassium concentration during the study period. Initially hardness, calcium and magnesium values were increased and after attaining maximum, they decreased. The decrease in concentration of calcium and magnesium might be due to their precipitation to $\mathrm{CaCO}_{3}$ and $\mathrm{Mg}(\mathrm{OH})_{2}($ Erses and Onay, 2003; Erses et al., 2008).

A decrease in chloride level during study period may be due to the quick anaerobic degradation of municipal solid waste in the lab scale (Sponza and Agdag, 2004). The initial sulphate concentration in leachate sample was $331 \mathrm{mg} \mathrm{l}^{-1}$, which was reduced to $138 \mathrm{mg} \mathrm{I}^{-1}$ (64\% reduction) at the end of the study period. Sulphide production can cause serious operational problems in anaerobic reactor that treat waste water with high sulphide concentration (Lens et al., 1998). At the end of the study, the phosphate content was reduced to $11.52 \mathrm{mg} \mathrm{l}^{-1}$ (75\% reduction), which might be due to assimilation of phosphate by microorganisms. The total Kjeldahl nitrogen in leachate sample increased to maximum ( $\left.1295 \mathrm{mg} \mathrm{l}^{-1}\right)$ on $7^{\text {th }}$ week of recirculation. After attaining maximum, a gradual decrease was observed. In nitrification and denitrification process during anaerobic decomposition of organic waste, $\mathrm{NH}^{4+}$ is converted to nitrogen gas and is lost to the atmosphere (Kuai and Verstraete, 1998; Elangovan and Sekar, 2015).

VFA is an important parameter because of the methanogenic stage and degree of stability of anaerobic
Table 1: Physico-chemical properties of MSW before leachate preparation and after completion of leachate treatment study

\begin{tabular}{lll}
\hline Parameters & Before treatment & After treament \\
\hline Moisture content $(\%)$ & 28.1 & 33.2 \\
pH & 7.8 & 7.3 \\
EC $\left(\mathrm{mS} \mathrm{cm}^{-1}\right)$ & 2.8 & 2.3 \\
TOC $\left(\mathrm{mg} \mathrm{g}^{-1}\right)$ & 48.3 & 27.4 \\
Calcium $\left(\mathrm{mg} \mathrm{g}^{-1}\right)$ & 15.0 & 6.8 \\
Magnesium $\left(\mathrm{mg} \mathrm{g}^{-1}\right)$ & 2.3 & 2.0 \\
Sulphate $\left(\mathrm{mg} \mathrm{g}^{-1}\right)$ & 6.0 & 4.7 \\
Phosphate $\left(\mathrm{mg} \mathrm{g}^{-1}\right)$ & 2.3 & 1.2 \\
TKN $\left(\mathrm{mg} \mathrm{g}^{-1}\right)$ & 35.0 & 15.0 \\
\hline
\end{tabular}

degradation process (Sponza and Agdag, 2004). In the present study, VFA increased from 4843 to $8280 \mathrm{mg} \mathrm{l}^{-1}$. This increase in VFA concentration may be as a result of accumulation of organic acids due to hydrolysis and acidogenesis. Later, VFA showed a decreasing trend and at the end of the study a $91 \%$ reduction was observed, which might be due to onset of methanogenesis.

The alkalinity of water is a measure of its capacity to neutralize acids and is primarily due to the salts of weak acids (Quasim and Chiang, 1994). The initial alkalinity level in leachate sample was $6400 \mathrm{mg} \mathrm{l}^{-1}$, which reduced to $1600 \mathrm{mg} \mathrm{l}^{-1}$ after completion of the experiment. This decrease in alkalinity might be due to dissolution and precipitation of metals carbonates (Bhambulkar, 2011). Except for last three days, alkalinity of the bioreactor was within the optimum range of anaerobic degradation. Alkalinity greater than $2000 \mathrm{mg} \mathrm{l}^{-1}$ in the bioreactor indicates optimum condition for methanogenesis (Bilgli et al., 2007).

It is essential that the reactor content provide enough buffering capacity to neutralize any eventual VFA accumulation to prevent build up of localized acid zones in the digester (Kanat et al., 2006). The degradation of protein by anaerobic treatment results in generation of alkalinity due to the reaction of ammonia with $\mathrm{CO}_{2}$ and water. Initially, VFA alkalinity ratio increased from 0.76 to 1.44 . After that it was gradually decreased and reached to minimum of 0.33 (Fig. 2). The VFAAlkalinity ratio was observed within the limits of optimum condition of anaerobic degradation i.e., less than 0.8 (Ehrig, 1983; Vlissidis and Zauboulis, 1993). This clearly demonstrates that performance of the reactor was excellent as VFAalkalinity ratio approached to less than 0.8 .

Chemical oxygen demand is a critical indicator of presence of biodegradable organics matter in leachate (Bhambulkar, 2011). The COD of leachate in the bioreactor increased significantly in the beginning i.e., $12747 \mathrm{mg} \mathrm{l}^{-1}$, which might be due to hydrolysis and leaching of soluble organic and inorganic compound from solid waste into leachate. After attaining maximum, COD reduction was observed. The anaerobic decomposition of simple organic compound into methane, carbon dioxide etc. is responsible for $\mathrm{COD}$ reduction. A $96 \%$ reduction in COD indicates that Leachate Recirculation Bioreactor 


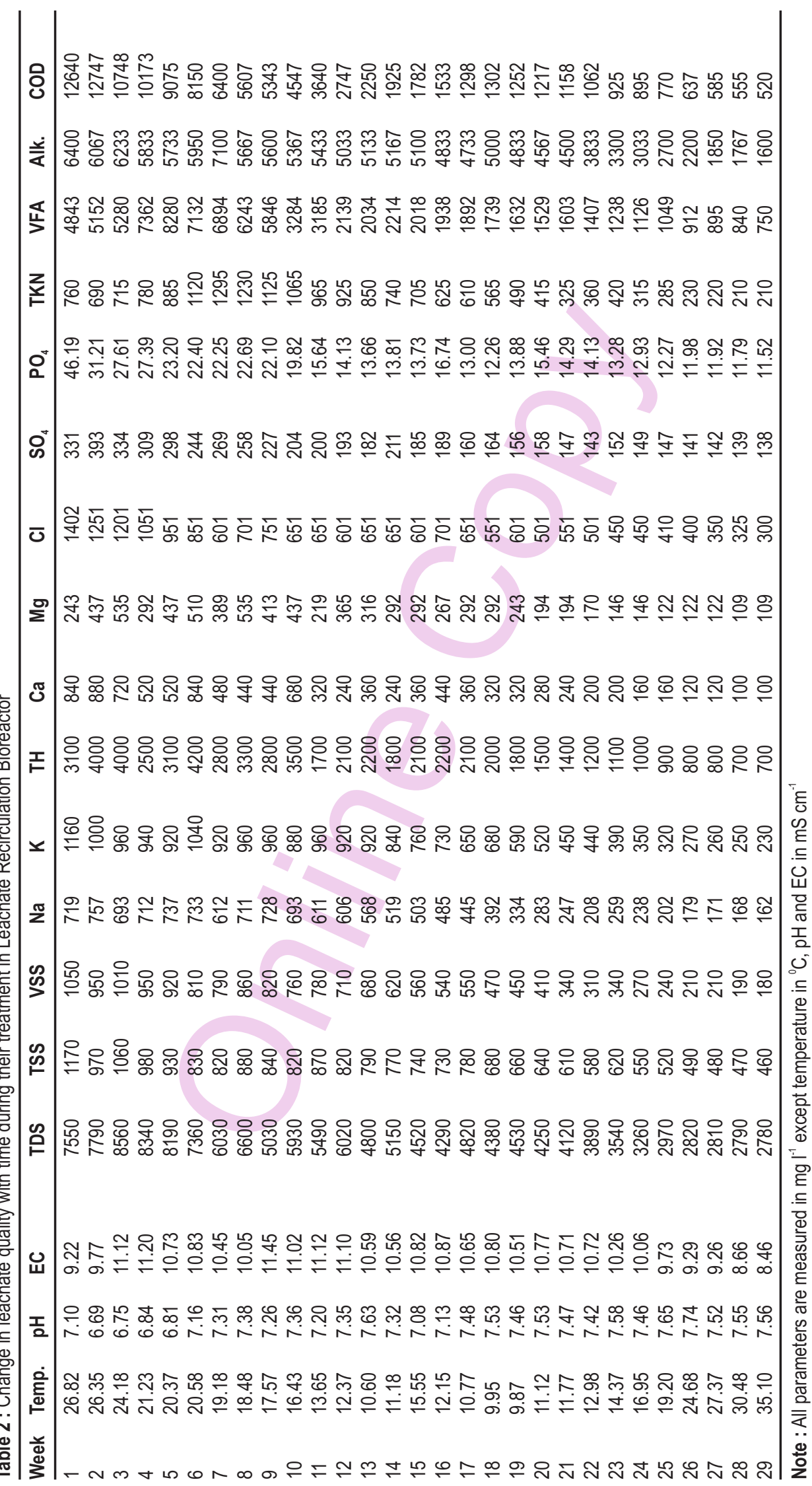


Table 3 : Quadric model showing change in variables with time

\begin{tabular}{|c|c|c|c|c|c|c|}
\hline Variable $(\mathrm{Y})$ & $a$ & $\beta$ & $Y$ & $\mathbf{R}^{2}$ & $\mathbf{F}$ & $p$ \\
\hline Temperature & $\begin{array}{l}3.680 \\
(41.182)\end{array}$ & $\begin{array}{l}-0.162 \\
(-11.802)\end{array}$ & $\begin{array}{l}0.005 \\
(11.995)\end{array}$ & 0.847 & 72.162 & 0.000 \\
\hline $\mathrm{pH}$ & $\begin{array}{l}1.914 \\
(142.822)\end{array}$ & $\begin{array}{l}0.008 \\
(3.807)\end{array}$ & $\begin{array}{l}0.000 \\
(-2.099)\end{array}$ & 0.691 & 29.062 & 0.000 \\
\hline Electric conductivity (EC) & $\begin{array}{l}2.266 \\
(97.235)\end{array}$ & $\begin{array}{l}0.022 \\
(6.175)\end{array}$ & $\begin{array}{l}-0.001 \\
(-7.660)\end{array}$ & 0.767 & 42.891 & 0.000 \\
\hline Total dissolve Solids (TDS) & $\begin{array}{l}9.067 \\
(179.989)\end{array}$ & $\begin{array}{l}-0.036 \\
(-4.621)\end{array}$ & $\begin{array}{l}0.000 \\
(-0.670)\end{array}$ & 0.948 & 238.197 & 0.000 \\
\hline Total suspended Solids (TSS) & $\begin{array}{l}6.956 \\
(214.612)\end{array}$ & $\begin{array}{l}-0.017 \\
(-3.444)\end{array}$ & $\begin{array}{l}0.000 \\
(-2.486)\end{array}$ & 0.958 & 296.745 & 0.000 \\
\hline Volatile suspended Solids (VSS) & $\begin{array}{l}6.925 \\
(201.263)\end{array}$ & $\begin{array}{l}-0.011 \\
(-2.035)\end{array}$ & $\begin{array}{l}-0.002 \\
(-10.447)\end{array}$ & 0.990 & 1323.575 & 0.000 \\
\hline Sodium (Na) & $\begin{array}{l}6.650 \\
(103.926)\end{array}$ & $\begin{array}{l}-0.003 \\
(-0.292)\end{array}$ & $\begin{array}{l}-0.002 \\
(-6.216)\end{array}$ & 0.965 & 361.742 & 0.000 \\
\hline Potassium (K) & $\begin{array}{l}6.884 \\
(166.659)\end{array}$ & $\begin{array}{l}0.021 \\
(3.282)\end{array}$ & $\begin{array}{l}-0.003 \\
(-12.471)\end{array}$ & 0.983 & 743.887 & 0.000 \\
\hline Total hardness $(\mathrm{TH})$ & $\begin{array}{l}8.182 \\
(85.693)\end{array}$ & $\begin{array}{l}-0.012 \\
(-0.803)\end{array}$ & $\begin{array}{l}-0.002 \\
(-3.442)\end{array}$ & 0.922 & 152.937 & 0.000 \\
\hline Calcium (Ca) & $\begin{array}{l}6.643 \\
(47.852)\end{array}$ & $\begin{array}{l}-0.039 \\
(-1.844)\end{array}$ & $\begin{array}{l}-0.001 \\
(1.469)\end{array}$ & 0.877 & 92.595 & 0.000 \\
\hline Magnesium (Mg) & $\begin{array}{l}5.946 \\
(49.811)\end{array}$ & $\begin{array}{l}0.019 \\
(1.042)\end{array}$ & $\begin{array}{l}-0.002 \\
(-3.996)\end{array}$ & 0.855 & 76.868 & 0.000 \\
\hline Chloride (Cl) & $\begin{array}{l}7.110 \\
(89.366)\end{array}$ & $\begin{array}{l}-0.051 \\
(-4.144)\end{array}$ & $\begin{array}{l}0.000 \\
(0656)\end{array}$ & 0.890 & 105.533 & 0.000 \\
\hline Sulphate $\left(\mathrm{SO}_{4}\right)$ & $\begin{array}{l}5.987 \\
(165.270)\end{array}$ & $\begin{array}{l}-0.071 \\
(-12.814)\end{array}$ & $\begin{array}{l}0.001 \\
(6.766)\end{array}$ & 0.965 & 357.221 & 0.000 \\
\hline Phosphate $\left(\mathrm{PO}_{4}\right)$ & $\begin{array}{l}3.671 \\
(54.696)\end{array}$ & $\begin{array}{l}-0.094 \\
(-9.160)\end{array}$ & $\begin{array}{l}0.002 \\
(5.762)\end{array}$ & 0.906 & 125.656 & 0.000 \\
\hline Total kjeldhal nitrogen (TKN) & $\begin{array}{l}6.669 \\
(65.952)\end{array}$ & $\begin{array}{l}0.049 \\
(3.177)\end{array}$ & $\begin{array}{l}-0.004 \\
(-7.149)\end{array}$ & 0.919 & 146.622 & 0.000 \\
\hline Volatile fatty acid (VFA) & $\begin{array}{l}9.023 \\
(63.221)\end{array}$ & $\begin{array}{l}-0.082 \\
(-3.740)\end{array}$ & $\begin{array}{l}-6.669 E^{-5} \\
(-0.094)\end{array}$ & 0.906 & 125.734 & 0.000 \\
\hline Alkalinity (Alk) & $\begin{array}{l}8.594 \\
(141.965)\end{array}$ & $\begin{array}{l}0.038 \\
(4.101)\end{array}$ & $\begin{array}{l}-0.003 \\
(-8.922)\end{array}$ & 0.944 & 217.669 & 0.000 \\
\hline Chemical oxygen demand (COD) & $\begin{array}{l}9.844 \\
(137.583)\end{array}$ & $\begin{array}{l}-0.177 \\
(-16.084)\end{array}$ & $\begin{array}{l}0.002 \\
(5.211)\end{array}$ & 0.988 & 1054.966 & 0.000 \\
\hline
\end{tabular}

performance was excellent. The reason for this decrease may be the quick degradation of the solid wastes in the lab scale anaerobic reactor (Sponza and Agdag, 2004). Similar trends of COD reduction were reported by Sanphoti et al., (2006) and Gawalpanchi et al. (2007). Thus, leachate recirculated bioreactor is an effective, faster and good option for MSW management (Snehlata et al., 2015 and Nain and Lohchab, 2015).

To capture the change in operating parameters over time, by using regression analysis, the quadric regression model was identified/selected on the basis goodness of fit criteria $\left(R^{2}\right)$. The estimated results of the model are presented in Table 3. The $R^{2}$ value of 0.691 or more and $p$ value (significance $F$ ) close to 0 of the quadric model showed that this model was best fit.

The quadric model showed that temperature, $\mathrm{SO}_{4}, \mathrm{PO}_{4}$ and $\mathrm{COD}$ decreased with time however, in diminishing amount. The rate of decrease in temperature, $\mathrm{SO}_{4}, \mathrm{PO}_{4}$ and $\mathrm{COD}$ were
$16.2 \%$ per unit time with diminishing amount of $0.5 \%, 7.1 \%$ per unit time with diminishing amount of $0.1 \%, 9.4 \%$ per unit time with diminishing amount of $0.2 \%$ and $17.7 \%$ per unit time with diminishing amount of $0.2 \%$, respectively (Table 3 ). Whereas, TDS, TSS and chloride are showing decreasing trends with per unit time but acceleration of change is zero. The amounts of decline per unit of time were $3.6 \%, 1.7 \%$ and $5.1 \%$ for TDS, TSS and chloride, respectively. The VSS, Na, TH, Ca and VFA were declined with time with increasing acceleration. The VFA has shown highest amount of decline with time but increase in acceleration was lowest.

The quadric model showed that EC, K, Mg, TKN and alkalinity increased with time. The amount of increase was highest in case of TKN $(4.9 \%)$ with highest diminishing rate of $0.4 \%$. The second highest amount of increase was observed in case of alkalinity. The rate of increase of $\mathrm{pH}$ with time was $0.8 \%$ though the change of acceleration was zero. 
Table 4 : Regression model showing effect of independent variables on COD

\begin{tabular}{|c|c|c|c|c|c|}
\hline Independent variable $(\mathrm{X})$ & $\bar{a}$ & $\beta$ & $r^{2}$ & $F$ & $p$ \\
\hline Temperature & $\begin{array}{l}6.403 \\
(4.171)\end{array}$ & $\begin{array}{l}0.473 \\
(0.877)\end{array}$ & 0.028 & 0.769 & 0.388 \\
\hline $\mathrm{pH}$ & $\begin{array}{l}51.338 \\
(8.579)\end{array}$ & $\begin{array}{l}-21.908 \\
(-7.287)\end{array}$ & 0.663 & 53.105 & 0.000 \\
\hline Electric conductivity (EC) & $\begin{array}{l}-5.758 \\
(-1.057)\end{array}$ & $\begin{array}{l}5.777 \\
(2.478)\end{array}$ & 0.185 & 6.142 & 0.000 \\
\hline Total dissolve solids (TDS) & $\begin{array}{l}-16.124 \\
(-12.146)\end{array}$ & $\begin{array}{l}2.814 \\
(17.991)\end{array}$ & 0.923 & 323.681 & 0.000 \\
\hline Total suspended solids (TSS) & $\begin{array}{l}-17.564 \\
(-9.756)\end{array}$ & $\begin{array}{l}3.845 \\
(14.064)\end{array}$ & 0.880 & 197.797 & 0.000 \\
\hline Volatile suspended solids (VSS) & $\begin{array}{l}-3.109 \\
(-3.937)\end{array}$ & $\begin{array}{l}1.739 \\
(13.787)\end{array}$ & 0.876 & 190.093 & 0.000 \\
\hline Sodium (Na) & $\begin{array}{l}-2.666 \\
(-3.008)\end{array}$ & $\begin{array}{l}1.727 \\
(11.785)\end{array}$ & 0.837 & 138.891 & 0.000 \\
\hline Potassium (K) & $\begin{array}{l}-3.958 \\
(-3.289)\end{array}$ & $\begin{array}{l}1.816 \\
(9.749)\end{array}$ & 0.779 & 95.050 & 0.000 \\
\hline Total hardness $(\mathrm{TH})$ & $\begin{array}{l}-5.274 \\
(-4.604)\end{array}$ & $\begin{array}{l}1.730 \\
(11.388)\end{array}$ & 0.828 & 129.695 & 0.000 \\
\hline Calcium (Ca) & $\begin{array}{l}-0.831 \\
(-1.090)\end{array}$ & $\begin{array}{l}1.489 \\
(11.304)\end{array}$ & 0.826 & 127.790 & 0.000 \\
\hline Magnesium (Mg) & $\begin{array}{l}-1.834 \\
(-1.518)\end{array}$ & $\begin{array}{l}1.730 \\
(7.955)\end{array}$ & 0.701 & 63.288 & 0.000 \\
\hline Chloride (Cl) & $\begin{array}{l}-8.260 \\
(-6.385)\end{array}$ & $\begin{array}{l}2.489 \\
(12.389)\end{array}$ & 0.850 & 153.476 & 0.000 \\
\hline Sulphate $\left(\mathrm{SO}_{4}\right)$ & $\begin{array}{l}-9.330 \\
(-10.317)\end{array}$ & $\begin{array}{l}3.235 \\
(18.906)\end{array}$ & 0.930 & 357.424 & 0.000 \\
\hline Phosphate $\left(\mathrm{PO}_{4}\right)$ & $\begin{array}{l}0.050 \\
(0.080)\end{array}$ & $\begin{array}{l}2.725 \\
(12.295)\end{array}$ & 0.848 & 151.157 & 0.000 \\
\hline Total kjeldhal nitrogen (TKN) & $\begin{array}{l}-1.832 \\
(-1.439)\end{array}$ & $\begin{array}{l}1.507 \\
(7.544)\end{array}$ & 0.678 & 56.907 & 0.000 \\
\hline Volatile fatty acid (VFA) & $\begin{array}{l}-2.676 \\
(-4.762)\end{array}$ & $\begin{array}{l}1.340 \\
(18.620)\end{array}$ & 0.928 & 346.708 & 0.000 \\
\hline Alkalinity (Alk) & $\begin{array}{l}-9.747 \\
(-4.161)\end{array}$ & $\begin{array}{l}2.088 \\
(7.473)\end{array}$ & 0.674 & 55.841 & 0.000 \\
\hline
\end{tabular}

The quadric model showed that COD had highest amount of decline with time but Sodium has lowest. Whereas, VFA has shown highest amount of increase with time but Magnesium has lowest. Quadric model also shows that $\mathrm{pH}$ and alkalinity were increased with time during the study period.

The effects of different operating parameters on COD were studied by cause and effect relationship through regression modeling. Except temperature and EC, all other parameters significantly affected the $\mathrm{COD}$ as $r^{2}$ values were more than 0.663 and $p$ values (significance $F$ ) were close to 0 (Table 4). The $1 \%$ increase of TDS, TSS, VSS, $\mathrm{Na}, \mathrm{K}, \mathrm{TH}, \mathrm{Ca}, \mathrm{Mg}, \mathrm{Cl}, \mathrm{SO}_{4}$, TKN, VFA and alkalinity resulted in $281.4 \%, 384.5 \%, 173.9 \%, 172.7 \%$, $181.6 \%, 173.0 \%, 148.9 \%, 173.0 \%, 248.9 \%, 323.5 \%, 150.7 \%$, $134.0 \%$ and $208.8 \%$ increase in COD, respectively. The regression models indicate that the $1 \%$ increase in $\mathrm{pH}$ resulted in $2190.8 \%$ decrease in COD.
Above trends of quadric modeling indicate that the organic and inorganic contaminants of leachate were decreased and $\mathrm{pH}$ and alkalinity were increased with time. During leachate recirculation a decrease in contaminants were also reported by Pohland et al. 1992; Filipkowska (2008); Snehlata et.al., 2015 and Nain and Lohchab, 2015.

High COD reduction of leachate at optimum $\mathrm{pH}$ and VFA alkalinity ratio suggests that the Leachate Recirculation Bioreactor technique can efficiently and effectively be used to treat leachate as well as stabilizes the MSW.

\section{Acknowledgment}

This research is based on the work supported by University Grant Commission under Major Research Project grant no. 39-337/2010(SR). Authors are thankful to Prof. Ved Pal, Haryana School of Business, Guru Jambheshwar University of 
Science and Technology, Hisar-125001 (Haryana) for his help in statistical analysis of this study.

\section{References}

Ahn, D. H., Y. C. Chung and W. S. Chang: Use of coagulant and zeolite to enhance the biological treatment efficiency of high ammonia leachate. J. Environ. Sci. Hlth., 37, 163-173 (2002).

APHA: Standard Methods for the Examination of Water and Waste Water. $22^{\text {nd }}$ Edn., American Public Health Association, Washington DC (2012).

Aziz, S. Q., H. A. Aziz, M. S. Yusoff, M. J. K. Bashir and M. Umar: Leachate characterization in semi-aerobic and anaerobic sanitary landfills: A comparative study. J. Environ. Manag., 91, 2608-2614 (2010).

Bhambulkar, A. V.: Effect of leachate recirculation on landfill. Int. J. Advan Engin. Sci. Technol., 11, 286-291 (2011).

Bilgili, M. S., A. Demir and B. O" zkaya: Influence of leachate recirculation on aerobic and anaerobic decomposition of solid wastes. J. Hazard. Mat., 143, 177-183 (2007).

Bohdziewicz, J. and A. Kwarciak A: The application of hybrid system UASB reactor-RO in landfill leachate treatment. Desalination, 222 , 128-134 (2008).

Bohdziewicz, J., M. Bodzek and J. Gorska: Application of pressure driven membrane techniques to biological treatment of landfill leachate. Process Biochem., 36, 641-646 (2001).

Chan, G. Y. S., L. M. Chu and M. H. Wong: Effects of leachate recirculation on biogas production from landfill co-disposal of municipal solid waste, sewage sludge and marine sediment. Environ. Poll., 118, 393-399 (2002).

Chen, C. K., S. L. Lo and T. Y. Chen: Regeneration and reuse of leachate from a municipal solid waste landfill. J. Environ. Biol., 35, 11231129 (2014).

Ehrig, H.J.: Quality and quantity of sanitary landfill leachate. Waste Manag. Res., 1, 53-68 (1983).

Elangovan, C. and A. S. S. Sekar: Performance evaluation of upflow anaerobic sludge blanket reactor process for dairy wastewater treatment. J. Environ. Biol., 36, 1305-1310 (2015)

Erses, S. and T. T. Onay: In situ heavy metal attenuation in landfills under methanogenic conditions. J. Hazard. Mat., 99, 159-175 (2003).

Erses, S., T. T. Onay and O. Yenigun: Comparison of aerobic and anaerobic degradation of municipal solid waste in bioreactor landfills. Biores. Technol., 99, 5418-5426 (2008).

Filipkowska, U.: Effect of recirculation method on quality of landfill leachate and effectiveness of biogas production. J. Environ. Stud., 17, 199-207 (2008).

Gawalpanchi, R. R., V.A. Mhaisalkar, S. Hiraou and A.D. Bhida: Treatment of leachate by recirculation through a bioreactor. In: Proceedings of the International Conference on Sustainable Solid Waste Management, Chennai, India, p. 460-465 (2007).

Han, Z., D. Liu and Q. Li:A removal mechanism for organics and nitrogen in treating leachate using a semi-aerobic aged refuse biofilter. J. Environ. Manag., 114, 336-342 (2013).

Kanat, G., A. Demir, B. Ozkaya and M.S. Bilgili: Addressing the operational problems in a composting and recycling plant. Waste Manag., 26, 1384-1391 (2006).

Kirmizakis, P., C. Tsamoutsoglou, B. Kayan and D. Kalderis: Subcritical water treatment of landfill leachate: Application of response surface methodology. J. Environ. Manag., 146, 9-15 (2014).

Kuai, L. and W. Verstraete: Ammonium removal by the oxygen-limited autotrophic nitrification-denitrification system. Appl. Environ. Microbiol., 64, 4500-4506 (1998).

Lens, P.N.L., A. Visser, A.J.H. Janssen, P.L.W. Hulshoff and G. Lettinga: Biotechnological treatment of sulphate-rich wastewaters. Crit. Rev. Environ. Sci. Technol., 28, 41-88 (1998).

Mor, S., K. Kaur and R. Khaiwal: SWOT analysis of waste management practices in Chandigarh, India and prospects for sustainable cities. J. Environ. Biol., 37, 327-332 (2016).

Murphy, R. J., D. E. Jones and R. I. Stessel: Relationship of microbial mass and activity in biodegradation of solid waste. Waste Manag. Res., 13, 485-497 (1995).

Nain, A. and R. K. Lohchab: Anaerobic treatment of MSW of Hansi in leachate recirculation bioreactor. Annals of Biology, 31, 46-50 (2015).

Pohland, F. G., W. H. Cross, J. P. Gould and D. R. Reinhart: The behaviour and assimilation of organic priority pollutants codisposed with municipal refuse. Vol.1, EPA Co-operation Agreement CR 812158, Cincinnati, Ohio (1992).

Pohland, F. G.: Sanitary Landfill Stabilization with Leachate Recycle and Residual Treatment, U.S. Environmental Protection Agency, EPA 600/2-75-043, Cincinnati, Ohio (1975).

Ponmani, S., C. Udayasoorian, R. M. Jayabalakrishnan and V. Kumar: Vermicomposting of paper mill solid waste using epigeic earthworm Eudrilus eugeniae. J. Environ. Biol., 35, 617-622 (2014).

Quasim, S. R. and W. Chiang: Sanitary landfill leachate. USA: Techonomic publishing company, ISBN 1-56676-129-8 (1994).

Reinhart, D. R. and A. B. Al-Yousfi: The impact of leachate recirculation on municipal solid waste operating characteristics. Waste Manag. Res., 14, 337-346 (1996).

Ryan, J., G. Estefan and A. Rashid: Soil and plant analysis laboratory manual. $2^{\text {nd }}$ Eds., ICARDA, Syria (2001).

Sanphoti, N., S. Towprayoon, P. Chaiprasert and A. Nopharatana: The effects of leachate recirculation with supplemental water addition on methane production and waste decomposition in a simulated tropical landfill. J. Environ. Manag., 81, 27-35 (2006).

Sartaj, M., M. Ahmadifar and A.K. Jaashni: Assessment of in-situ aerobic treatment of municipal landfill leachate at laboratory scale. Iranian J. Sci. Technol., Transac. B. Engin., 34, 107-116(2010).

Snehlata, R. Lohchab and A. Nain: Anaerobic treatment of MSW using leachate recirculation bioreactor: A case study of Rohtak City. Nature Environ. Poll. Technol., 14, 919-922 (2015).

Sponza, D.T. and O.N. Agdag: Impact of leachate recirculation and recirculation volume on stabilization of municipal solid waste in simulated anaerobic bioreactors. Process Biochem., 39, 21572165(2004).

Vlissidis, A. and A.J. Zouboulis: Thermophilic anaerobic digestion of alcohol distillery wastewaters. Biores. Technol., 43, 131-140 (1993). 